\title{
Copper removal efficiency in a surface water and compartmentalization in the floating fern Salvinia minima
}

\author{
María Victoria Casares ${ }^{1, *}$, Laura I. de Cabo ${ }^{1}$, Rafael S. Seoane ${ }^{2,3}$, Alicia Fabrizio de Iorio ${ }^{4}$ \\ ${ }^{1}$ Bernardino Rivadavia National Museum of Natural History-National Council of Scientific and Technical Research (CONICET), Avenida \\ Ángel Gallardo 470 (C1405DJR), Buenos Aires, Argentina \\ ${ }^{2}$ Faculty of Engineering, University of Buenos Aires, Avenida Las Heras 2214, (C1127AAR), Buenos Aires, Argentina \\ ${ }^{3}$ National Water Institute, Autopista Ezeiza-Cañuelas, Tramo Jorge Newbery km 1.62 (1802) Ezeiza, Buenos Aires, Argentina \\ ${ }^{4}$ Faculty of Agronomy, University of Buenos Aires, Avenida San Martín 4453 (C1417DSE), Buenos Aires, Argentina
}

\section{Email address:}

mvc251@hotmail.com (M. V. Casares), ldecabo@macn.gov.ar (L.de Cabo), rseoane@ina.gov.ar (R. Seoane), aliorio@yahoo.com.ar (A. F. de Iorio)

\section{To cite this article:}

María Victoria Casares, Laura I. de Cabo, Rafael S. Seoane, Alicia Fabrizio de Iorio. Copper Removal Efficiency in a Surface Water and Compartmentalization in the Floating Fern Salvinia minima. International Journal of Environmental Monitoring and Analysis. Special Issue: Environmental Science and Treatment Technology. Vol. 2, No. 6-1, 2014, pp. 42-47. doi: 10.11648/j.ijema.s.2014020601.16

\begin{abstract}
In order to determine copper removal efficiency and compartmentalization in the free floating fern S. minima, a bioassay was performed in which plants were exposed to increasing copper concentrations in the range of 1 to $30 \mathrm{mg} \mathrm{Cu} \mathrm{L}^{-1}$ for six days in Pilcomayo River surface water. S. minima accumulated the metal in a dose-dependent manner. Metal concentration was from 6.5 to 3.9 times higher in the submerged biomass in comparison to the aerial biomass in all treatments reflecting a poor mobility of copper between plant tissues. In both biomasses, most of the copper was localized in the extracellular compartment and increased lineally with increasing concentration of copper in water. The intracellular fraction increased following a polynomial function. The physicochemical characteristics of the experimental water influenced copper bioavailability inducing copper precipitation and the high concentration of calcium may have exerted a protective effect limiting metal entrance to cells. The values of the BCF and of the dry biomass weight that corresponded to copper showed that in Pilcomayo River water $S$. minima showed a copper removal efficiency not of a hyperaccumulator but of an effective accumulator.
\end{abstract}

Keywords: Salvinia minima, Copper Uptake, Extracellular and Intracellular Compartments, Surface Water

\section{Introduction}

Metals releases to the aquatic ecosystems come mostly from anthropogenic activities such as mining and smelting, industrial emissions and effluents, municipal wastes and sewage sludge. Some heavy metals are essential nutrients, necessary for the normal growth and metabolism of all living organisms and copper is an example. In plants copper is a component of various proteins particularly those involved in both the photosynthetic (plastocyanin) and the respiratory (cytochrome oxidase) electron transport chains [1]. However, high concentrations of copper may account for leaf chlorosis, iron deficiency and inhibition of root growth by damaging plasma membrane integrity [2].

Although it may be possible to reduce the toxicity of metals by influencing their speciation, they are not degraded. Therefore, the primary goal is to reduce their concentrations in the environment. Several methods are used to clean up the environment from these kind of pollutants each one with its benefits and limitations. One of the methods which has gained considerable importance in the last decades is phytoremediation, which offers significant advantages like low-cost, availability, profitability, easy operation and efficiency [3]. In reference to wastewater treatment and surface waters remediation, many aquatic macrophytes were found to be potential scavengers of metals from the aquatic environment and are already being used in wastewater treatment systems.

Salvinia minima (Baker, 1886) is an aquatic free floating fern with a wide distribution in tropical and subtropical areas which has shown a large capacity to accumulate lead and cadmium [4]. In addition, S. minima has a fast growing rate, dense pseudoroots system and is tolerant to pollution, favorable properties in species to be used in phytoremediation. In developing countries, liquid wastes from many industrial 
units, mine and processing plants contain comparatively high (and hence, unacceptable for the environment) concentration of heavy metals. Consequently, to evaluate the possibility of reducing metal concentration in effluents and surface waters through phytoremediation, bioassays should incorporate a wide range of metal concentrations, including those very high concentrations that can reach surface waters when mine or industrial waste waters spills occur. Furthermore, performing bioassays in natural waters makes them more realistic since surface waters present a complexity which cannot be replicated in test media. In this regard, Pilcomayo River (South America) presents extreme water quality characteristics due to its high concentrations of calcium, sodium, (bi)carbonate, sulphates, and total suspended solids.

Metals phytoaccumulation process in aquatic plants usually consists of two stages: an initial phase of reversible metal binding (biosorption) followed by a slower irreversible process (bioaccumulation). According to several authors [5] metals may accumulate in the extracellular compartment (dissolved in liquids surrounding cells, forming deposits on cells and those temporarily bound in exchangeable form to charged groups forming part of components of the cell wall or of the outer surface of the plasma membrane) and/or in the intracellular compartment (contained within the cell itself, whether in soluble or insoluble form).

The importance of discerning metal contents in each of the major compartments (extracellular and intracellular; aerial and submerged biomass) will determine the best treatment method related to handling and disposal of contaminated plant biomass. It also gives insights into tolerant plants strategy to cope with high heavy metals concentrations in the environment. Generally, EDTA (Ethylenediaminetetraacetic acid) is one of the more widely used extractants in the analysis of metals compartmentalization in plants. More recently, compartmentalization analysis was applied to macrophytes [6, 7], encouraged by the use of emergent or floating aquatic plants for heavy metals removal from wastewaters.

The aim of this contribution was to assess $S$. minima copper removal efficiency in a surface water and investigate metal compartmentalization within the intracellular and extracellular compartments in the aerial and submerged biomass.

\section{Materials and Methods}

\subsection{Copper Removal}

S. minima used in the experiment were collected from monocultures mantained outdoors in the Bernardino Rivadavia National Museum of Natural History. The plants were rinsed gently with distilled water and placed in plastic containers with tap water to allow acclimation to experimental conditions for at least one week. Later, plants were acclimated to test water for 2 days.

Pilcomayo River water was collected in Misión La Paz

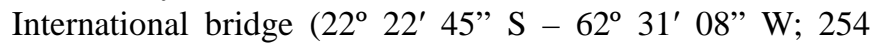
meters over sea level) in May 2009. Misión La Paz is located in the Province of Salta, Argentina, approximately, $500 \mathrm{~km}$ downstream Cerro Rico de Potosí mining district (Bolivia). Water samples were collected in pre-rinsed 10-L polypropylene containers. Samples were immediately placed into coolers and transported by plane to the laboratory. Pilcomayo River water presents a very high load of total suspended solids, thus, to avoid metal sorption to these solids, water was centrifuged (2000 RPM during 15 minutes) and filtered through $47 \mathrm{~mm} 0.45 \mu \mathrm{m}$ pore glass-fiber filters (Whatman GF/C). Dissolved concentrations of calcium (Ca), magnesium $(\mathrm{Mg})$, chloride $(\mathrm{Cl})$, potassium $(\mathrm{K})$, sodium $(\mathrm{Na})$, sulphate $\left(\mathrm{SO}_{4}\right)$, hardness (Hard), alkalinity (Alk), dissolved organic carbon (DOC), total suspended solids (TSS), total dissolved solids (TDS), total (T. Cu) and dissolved copper (D. $\mathrm{Cu}$ ) concentrations were determined using Standard Methods test protocols [8]. Background copper concentration in Pilcomayo River water was below the method detection limit.

Experimental glass aquaria contained a river water volume of $1 \mathrm{~L}$ and S. minima biomass that totalized 300 fronds with a size $\geq 3 \mathrm{~mm}$. During the bioassay, plants were exposed to natural photoperiod and a temperature of $19 \pm 2{ }^{\circ} \mathrm{C}$. Plants were in contact with copper in solution for six days and the experimental design included five different copper concentrations (treatments) with one control group (kept in test water and without copper addition). Test copper concentrations were attained by spiking from a stock solution of $100 \mathrm{mg} \mathrm{Cu} \mathrm{L}^{-1}$. The toxicant used was reagent-grade $\mathrm{CuSO}_{4}$. The range of copper concentrations tested was from 1 to 30 $\mathrm{mg} \mathrm{Cu} \mathrm{L}{ }^{-1}$.

Water temperature, $\mathrm{pH}$ and electrical conductivity were measured daily. Immediately after copper addition, water samples were collected into polypropylene conical tubes and acidified to $\mathrm{pH}<2$ with concentrated nitric acid (reagent-grade) for metal analysis.

\subsection{Analysis of Compartmentalization}

To assess metal localization among the extracellular and intracellular compartments in $S$. minima biomass, a compartmentalization analysis was performed. The methodology applied was previously described by [6]. Once ended the bioassay, total biomass in each experimental container was quickly rinsed with distilled water and separated into aerial (fronds) and submerged biomass (pseudoroots+ rhizome). Both biomasses were washed with a solution of EDTA $10 \mathrm{mM}$ for 30 minutes in a shaker. The biomass washed was placed in a container with $100 \mathrm{ml}$ distilled water and shaked again for 30 minutes. Both washing solutions were mixed and acidified to $\mathrm{pH}<2$ with concentrated nitric acid (reagent-grade) to determine metal concentration (extracellular metal) after acid digestion $\left(\mathrm{HNO}_{3}: \mathrm{HClO}_{4}: \mathrm{HNO}_{3}: \mathrm{HCl}\right)$.

To determine the dry weights, the biomass previously washed with EDTA and water was dried at $60{ }^{\circ} \mathrm{C}$ for 48 hours. Intracellular metal concentration was determined after acid digestion $\left(\mathrm{HNO}_{3}: \mathrm{HClO}_{4}: \mathrm{HNO}_{3}: \mathrm{HCl}\right)$ in both the aerial and the submerged biomass previously dried.

All metal determinations in water samples and biomass 
were performed by atomic absorption spectrophotometry (Perkin Elmer 1100B, Perkin Elmer, Inc., Waltham, MA, USA). Method copper detection limit was $0.01 \mathrm{mg} \mathrm{L}^{-1}$.

The speciation program Visual MINTEQ version 3.0 (http://www2.lwr.kth.se/English/Oursoftware/vminteq/), was applied to obtain copper speciation on each of the concentrations measured at the beginning of the bioassay.

Assuming that metal uptake mainly occurs in S. minima submerged biomass, the Translocation Factor (TF) was calculated to determine copper mobility within plant tissues according to the following equation:

$$
\mathrm{TF}=\frac{\text { Metal concentration in aerial biomass }\left(\mathrm{mg} \mathrm{kg} \mathrm{dw}^{-1}\right)}{\text { Metal concentration in submerged biomass }\left(\mathrm{mg} \mathrm{kg} \mathrm{dw}^{-1}\right)}
$$

Finally, as indicators of $S$. minima copper removal efficiency the Bioconcentration Factor (BCF) according to [9] and the percentage of total dry biomass weight corresponding to copper were calculated.

$$
\mathrm{BCF}=\frac{\text { Metal in total biomass }\left(\mathrm{mg} \mathrm{kg} \mathrm{dw}^{-1}\right)}{\text { Metal initial concentration in solution }\left(\mathrm{mg} \mathrm{L}^{-1}\right)}
$$

\section{Results}

Main physicochemical parameters in Pilcomayo River test water are shown in Table 1. As it can be observed, this water was characterized by elevated hardness, sulphates and chloride concentrations.

Mean test water temperature and $\mathrm{pH}$ were $18.5 \pm 1.2^{\circ} \mathrm{C}$ and $8.09 \pm 0.22 \mathrm{UpH}$, respectively. The initial dissolved copper concentrations in the different treatments were measured in water samples collected immediately after metal addition. The values obtained were $2.4\left(\mathrm{~T}_{1}\right), 5.2\left(\mathrm{~T}_{2}\right), 17.5\left(\mathrm{~T}_{3}\right), 21\left(\mathrm{~T}_{4}\right)$, and $28\left(\mathrm{~T}_{5}\right) \mathrm{mg} \mathrm{Cu} \mathrm{L}^{-1}$. In the control group, metal concentration was below the method detection limit. During the first few hours from the beginning of the bioassay, water in treatments $\mathrm{T}_{4}$ and $\mathrm{T}_{5}$ turned light blue. This indicated copper precipitation as a colloide. Plants general appearence was good during all bioassay in all treatments and no growth differences were recorded between treatments (final aerial, submerged and total biomass ranged from 0.64 to $0.73,0.3$ to 0.4 and 0.93 to $1.11 \mathrm{~g}$ dw, respectively).

Table 2 shows copper concentration in S. minima aerial, submerged and total biomass in each treatment at the end of the bioassay. Total copper concentration in S. minima whole plant biomass, the aerial and the submerged tissues increased with increasing metal concentration in solution and the highest removal occurred in $\mathrm{T}_{5}$. In general, metal concentration was from 6.5 to 3.9 times higher in the submerged biomass in comparison to the aerial biomass in all treatments. In $\mathrm{T}_{3}$, however, copper concentration in the submerged biomass was 8 times more elevated than in the aerial biomass.

Table 1. Pilcomayo River surface water main physicochemical parameters (data provided by Subsecretaria de Recursos Hidricos - Argentina). (ND: not detected)

\begin{tabular}{lll}
\hline Parameter & & \\
\hline $\mathrm{EC}$ & $\mu \mathrm{S} / \mathrm{cm}$ & 945.3 \\
$\mathrm{Ca}^{2+}$ & $\mathrm{mg} \mathrm{L}^{-1}$ & 73.33 \\
$\mathrm{Mg}^{2+}$ & $\mathrm{mg} \mathrm{L}^{-1}$ & 30.5 \\
$\mathrm{Hardness}$ & $\mathrm{mg} \mathrm{L}^{-1} \mathrm{CaCO}_{3}$ & 307.32 \\
$\mathrm{Cl}^{-}$ & $\mathrm{mg} \mathrm{L}^{-1}$ & 101 \\
$\mathrm{Na}^{+}$ & $\mathrm{mg} \mathrm{L}^{-1}$ & 65.2 \\
$\mathrm{~K}^{+}$ & $\mathrm{mg} \mathrm{L}^{-1}$ & 5.1 \\
$\mathrm{SO}_{4}{ }^{2-}$ & $\mathrm{mg} \mathrm{L}^{-1}$ & 207.3 \\
$\mathrm{DOC}^{-1}$ & $\mathrm{mg} \mathrm{L}^{-1}$ & 4.4 \\
$\mathrm{Alk}$ & $\mathrm{mg} \mathrm{L}^{-1} \mathrm{CaCO}_{3}$ & 110 \\
$\mathrm{TSS}$ & $\mathrm{mg} \mathrm{L}^{-1}$ & 1637 \\
$\mathrm{TDS}$ & $\mathrm{mg} \mathrm{L}^{-1}$ & 517 \\
$\mathrm{~T} . \mathrm{Cu} / \mathrm{D} . \mathrm{Cu}$ & $\mathrm{mg} \mathrm{L}^{-1}$ & $0.07 / \mathrm{ND}$ \\
\hline
\end{tabular}

Table 2. Copper concentration in S. minima aerial, submerged and whole plant biomass and copper concentration in the extracellular and the intracellular

\begin{tabular}{|c|c|c|c|c|c|c|c|}
\hline \multirow{3}{*}{ Treatments } & \multicolumn{7}{|c|}{ Final copper concentration in biomass $\left(\mathrm{mg} \mathrm{g} \mathrm{dw}^{-1}\right)$} \\
\hline & \multicolumn{3}{|c|}{ Aerial } & \multicolumn{3}{|l|}{ Submerged } & \multirow{2}{*}{ Whole plant } \\
\hline & Intracellular & Extracellular & Total & Intracellular & Extracellular & Total & \\
\hline Control & 0.005 & 0.02 & 0.02 & 0.005 & 0.13 & 0.13 & 0.64 \\
\hline $\mathrm{T}_{1}$ & 0.07 & 0.47 & 0.54 & 0.08 & 2.83 & 2.91 & 1.38 \\
\hline $\mathrm{T}_{2}$ & 0.07 & 0.92 & 0.99 & 0.38 & 7.66 & 8.04 & 3.45 \\
\hline $\mathrm{T}_{3}$ & 0.86 & 1.87 & 2.74 & 0.99 & 12.86 & 13.85 & 6.33 \\
\hline $\mathrm{T}_{4}$ & 0.83 & 2.27 & 3.11 & 1.01 & 14.36 & 15.36 & 7.71 \\
\hline
\end{tabular}
compartments determined at the end of the exposure period in each treatment.

The main copper fraction in plant biomass was the extracellular (Table 2). In the submerged biomass, this fraction was from 6.5 to 5.7 times higher than in the aerial biomass and increased with increasing copper concentration in water (Fig. 1A). This increment was better described by a lineal function both in the aerial $\left(y=0.098 x+0.2026, R^{2}=\right.$ $0.99)$ and the submerged biomass $\left(y=0.5643 x+2.11, R^{2}=\right.$ 0.94). Small differences were recorded in the intracellular concentration of copper between the aerial and the submerged biomass in the control group and $\mathrm{T}_{1}$ (Fig. 1B). In contrast, from $\mathrm{T}_{2}$ to $\mathrm{T}_{5}$, the intracellular concentration of copper showed a notable increment that adjusted to a polynomial function (y $=0.0032 \mathrm{x}^{2}-0.011+0.123, \mathrm{R}^{2}=0.96$ and $\mathrm{y}=0.0025 \mathrm{x}^{2}-$ $0.0061+0.037, \mathrm{R}^{2}=0.97$, in the submerged and the aerial biomass, respectively).

Fig. 2A and 2B show the extracellular and the intracellular copper fractions expressed as percentages of the total copper content in the aerial and the submerged biomass, respectively. In the aerial biomass (Fig. 2A), the percentage of intracellular copper in the control group was $22.3 \%$. It decreased in $\mathrm{T}_{2}$ reaching $7.5 \%$ and then increased with increasing copper concentration in water reaching $39.5 \%$ in $\mathrm{T}_{5}$. In the submerged 
biomass (Fig. 2B), the percentage of copper within the cells in the control group was $3.9 \%$ and this percentage increased with increasing copper concentration in water to reach $12.7 \%$ in $\mathrm{T}_{5}$.

Visual MINTEQ speciation estimates showed that in all treatments most of the copper initially measured precipitated (>90\%), remaining in solution $0.14 \mathrm{mg} \mathrm{Cu} \mathrm{L}^{-1}$ most of which was complexed to dissolved organic matter $(85.4 \%)$ and to carbonates, to a lesser extent $(12.5 \%)$.

The BCF (Table 3) calculated for the submerged and whole plant biomass showed an increment from $\mathrm{T}_{1}$ to $\mathrm{T}_{2}$, reduced almost by half in $\mathrm{T}_{3}$ and tended to decrease with increasing copper concentration in water. The percentage of whole plant dry biomass corresponding to copper showed a marked increasing trend throughout evaluated concentrations. From plants in the control group to $\mathrm{T}_{1}$, this variable increased in two orders of magnitude. The values of the TF were low in all treatments and showed a slight increasing trend indicating lower translocation to the aerial tissues as copper concentration increased in the submerged tissues.
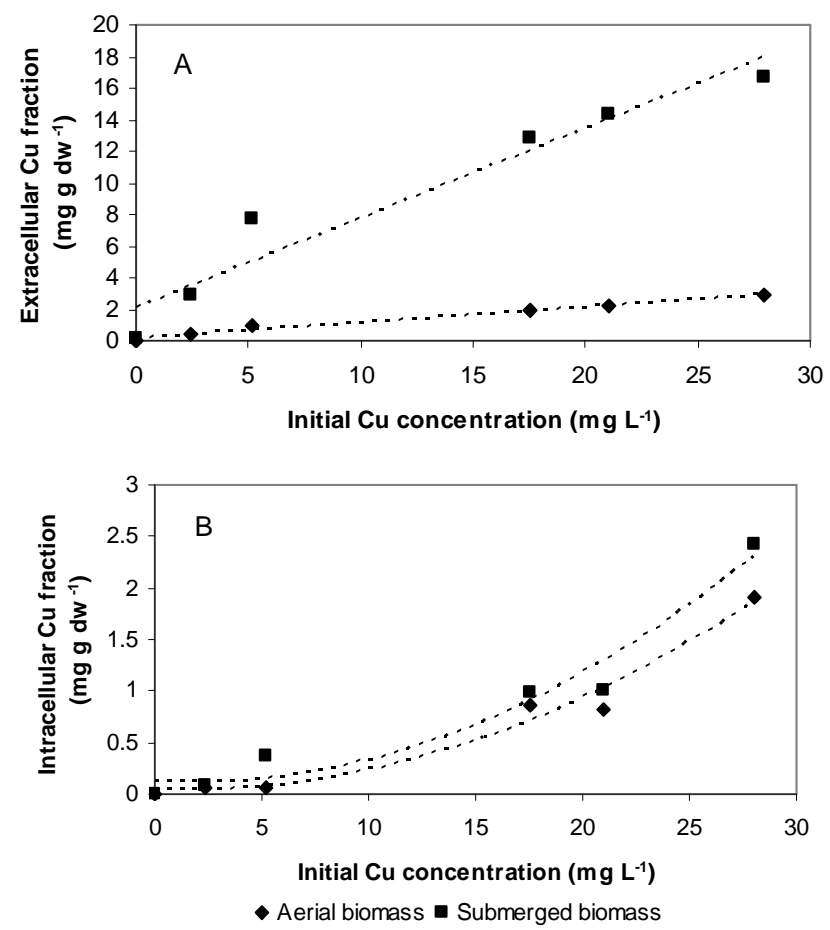

Figure 1. Copper concentration in the extracellular (A) and the intracellular (B) compartments in S. minima aerial and submerged biomass determined at the end of the exposure period.

Table 3. Bioconcentration Factor (BCF), Translocation Factor (TF) and percentage of whole plant dry biomass corresponding to copper $(\% \mathrm{dw} C u)$ in each treatment determined at the end of the exposure period.

\begin{tabular}{llll}
\hline Treatments & BCF & \% dw Cu & TF \\
\hline Control & - & 0.006 & 0.17 \\
$\mathrm{~T}_{1}$ & 578.5 & 0.14 & 0.18 \\
$\mathrm{~T}_{2}$ & 664.4 & 0.34 & 0.12 \\
$\mathrm{~T}_{3}$ & 361.8 & 0.62 & 0.20 \\
$\mathrm{~T}_{4}$ & 367.4 & 0.77 & 0.20 \\
$\mathrm{~T}_{5}$ & 351.7 & 0.97 & 0.25 \\
\hline
\end{tabular}

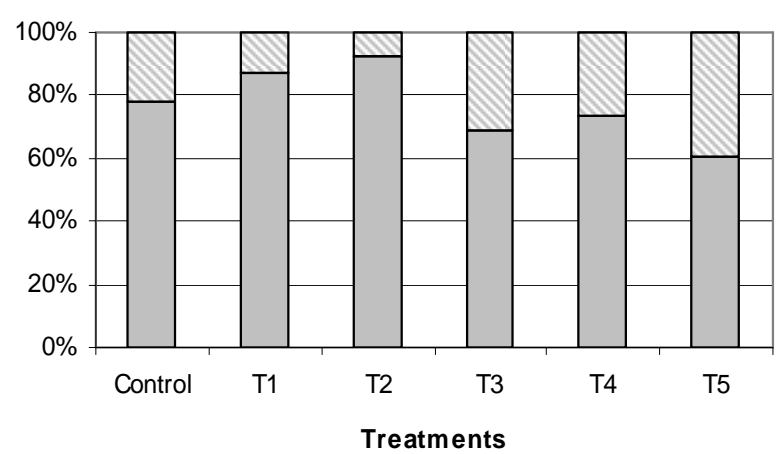

(A)

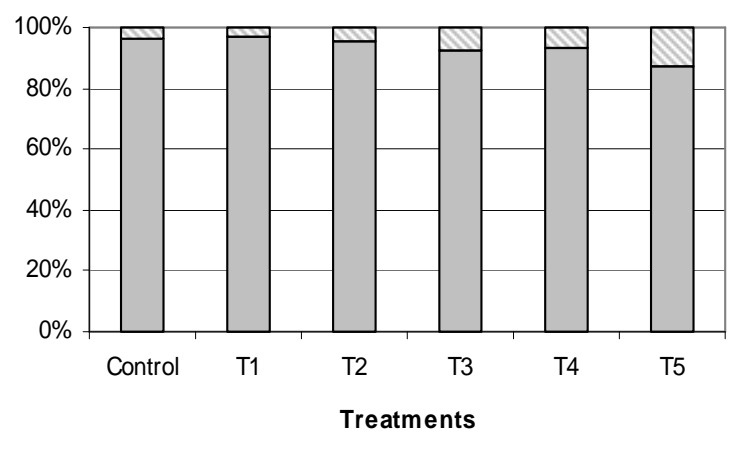

$\square$ Extracellular $\mathrm{Cu}$ intracellular $\mathrm{Cu}$

(B)

Figure 2. Copper concentration in the extracellular and intracellular compartments expressed as percentages of total copper concentration in $S$. minima aerial $(A)$ and submerged $(B)$ biomass.

\section{Discussion}

Copper critical concentration in aerial tissues of terrestrial plants is within the range of 0.02 to $0.03 \mathrm{mg} \mathrm{g} \mathrm{dw}^{-1}[10,11]$. Generally, when this limit is surpassed, plants begin to show symptoms of toxicity. For aquatic plants, no such a critical concentration of copper can be found in the literature. In our study, the concentration of copper measured in the aerial biomass of plants from the control group was within the range of critical toxicity values previously mentioned for terrestrial plants. Moreover, these values have confirmed previous determinations that we have performed in S. minima biomass (data not published). In the literature, very few studies inform copper concentrations in aquatic plants from control groups. Ater et al. [12] informed for Lemna minor and Lemna gibba plants, copper concentrations of 0.1 and $0.09 \mathrm{mg} \mathrm{g} \mathrm{dw}^{-1}$, respectively, and for Eichhornia crassipes, Melignani et al. [personal communication] measured a concentration of copper in the range of $0.004-0.05$ and $0.004-0.012 \mathrm{mg} g$ $\mathrm{dw}^{-1}$ for roots and leaves tissues, respectively, showing a considerable range of variation in control plants. In view of these values, it is worth asking if copper basal levels in aquatic plants are higher than in terrestrial plants or if copper accumulation in S. minima and other species known as tolerant or hypertolerant is constitutive, deriving in high metals concentrations in plants growing in non-polluted waters. In this regard, [13] mentioned that in the terrestrial species Arabidopsis halleri, zinc hyperaccumulation is constitutive 
but with a heritable variation in degree between local populations.

No previous study on $S$. minima metals uptake showed a distinction between metal accumulation in the aerial and the submerged biomass and the results obtained in our study showed that copper concentration in the submerged biomass exceeded that in the fronds. This pattern is in line with previuos observations by other authors in other aquatic free floating plants. Sela et al. [14] also found for other aquatic free floating fern, Azolla filiculoides, that copper was mainly localized in the roots. Maine et al. [15] reported that when Salvinia herzogii and Pistia stratiotes were in contact with chromium and cadmium in solution, a higher concentration of these metals was observed in the submerged biomass compared to the aerial biomass. Although copper concentration increased in both tissues with increasing metal concentration in water, the concentration itself and the rate of increment reflected a poor mobility of copper to the aerial tissues.

In reference to copper localization between the extracellular and the intracellular compartments, the analysis performed allowed us to determine that most of the copper was localized in the extracellular compartment in both biomasses, and increased with an obvious higher rate in the submerged biomass. In this regard, and making use of the X-ray microanalysis, various authors [14, 16-18] have shown that metals in the extracellular compartment are mainly associated to cell walls, suggesting apoplastic tissue translocation and/or metal storage in the apoplast where metal can do no harm to cellular processes [19]. In Azolla pinnata, Spirodela polyrrhiza [6] and in some species of bryophytes [5, 20], it has also been reported that most of the metals are accumulated in the extracellular compartment. The relevance of these findings is directly related to the advantages and hazards of the different methods for plants handling, metal recover or disposal in the case some of these species is selected for phytoremediation.

The intracellular concentration of copper, on the other hand, increased in both biomasses with differences in the rate of increment only in the highest concentration tested. When expressed as percentage of total copper content in biomass, the percentage of intracellular copper was higher in the aerial than in the submerged biomass. This is most probably owned to copper participation in the photosynthetic electron transport [19]. In the case of iron, within the cells the chloroplasts are a well-known sink compartment since the electron transport chains use it as cofactor [18]. For copper, storage within the intracellular compartment has yet not been established.

In our study, S. minima showed high tolerance to elevated concentrations of copper in water and accumulated the metal in a dose-dependent manner. Moreover, the highest copper removal was observed in the treatment with the highest initial copper concentration. A similar trend was also reported for Centella asiatica and E. crassipes [21] and for L. gibba [22]. In the literature, there is one previous work on the evaluation of copper uptake by S. minima. Al-Handami and Blair [2] studied copper removal by this species in a range of copper concentrations from 0.06 to $3 \mathrm{mg} \mathrm{L}^{-1}$ and reported a maximum removal of $3.5 \mathrm{mg} \mathrm{g}^{-1} \mathrm{dw}$, when plants were exposed to metal in solution for 7 days. In our study, S. minima showed lower uptake values. Nevertheless, S. minima was exposed to copper in Pilcomayo River surface water which presents low key nutrients concentrations and particular physicochemical characteristics which might have had some influence on copper bioavailabity and/or toxicity.

On the one hand, water $\mathrm{pH}$ induced metal precipitation. According to the speciation estimates of the speciation program Visual MINTEQ, most of the copper initially in solution precipitated. Therefore, plants may have possibly been in contact with a higher concentration of copper in its free ionic form during the first minutes to hours of the bioassay. Studies on the kinetics of heavy metals uptake by aquatic plants have revealed an initial phase of fast metal removal followed by a lineal slower phase [23] and, in accordance with this, [4] found that S. minima lead and cadmium uptake was $55 \%$ and $60 \%$, respectively, during the first 4 to 6 hours of their bioassay. May S. minima's copper removal uptake been higher without metal precipitation? It should be determined.

On the other hand, Pilcomayo river water also presents high concentrations of the major ions, principally, calcium and magnesium, which derives in a water with elevated hardness (307.32 $\mathrm{mg} \mathrm{L}^{-1} \mathrm{CaCO}_{3}$ ). In terrestrial plants the role of calcium in inhibiting lead uptake has been demonstrated, whereas, for other metals, this inhibition has not been observed. Wang et al. [24] have investigated the alleviation of copper toxicity by other coexisting cations in the medium and found that the addition of these cations reduces the activity of $\mathrm{Cu}^{2+}$ at the plasma membrane surface by means of an electrostatic effect and that site-specific competition may exist in plants but to a lesser extent than in animals. According to these observations, the high level of calcium in Pilcomayo River water might have contributed in reducing copper entrance to cells.

To assess the hyperaccumulation ability of a plant species [9] proposed that a species can be considered a hyperaccumulator when: a) metal adsorbed and bioaccumulated represents more than $0.5 \%$ of its dry weight and b) the $\mathrm{BCF}>1000$. The BCF obtained in the present contribution showed to be $<1000$ in all treatments. The dry biomass weight that corresponded to copper, in turn, showed an increasing trend and was $>0.5 \%$ in the highest concentrations tested. Hence, when both criterions are considered, the results obtained indicate that S. minima would not be a hyperaccumulator of copper, however, it can be considered an effective accumulator and this property is not reflected by its ability to bioconcentrate the metal, but by its ability to remove metal from water. For L. gibba and L. minor [12] reported bioconcentration factors in the range of 380-149 when plants were exposed to copper concentrations of 1 to $5 \mathrm{mg}$ $\mathrm{Cu} \mathrm{L}^{-1}$, respectively, reflecting that these lemnaceas may also not show an hyperaccumulation capacity for copper uptake.

\section{Acknowledgements}

This research was supported by two grants of the University of Buenos Aires (UBACyT 20020100100135 and UBACyT 
IO-28). The authors want to thank EVARSA and Subsecretaría de Recursos Hídricos-Argentina (SsRH), who kindly performed water sampling and monitoring operations at Misión La Paz and Comisión Trinacional para el Desarrollo de la Cuenca del Río Pilcomayo for providing additional Pilcomayo River water quality data.

\section{References}

[1] K. Demirevska-Kepova, L. Simova-Stoilova, Z. Stoyanova, R Holzer, and U. Feller, "Biochemical changes in barley plants after excessive supply of copper and manganese" Environ. Exp. Bot., vol. 52, pp. 253-266, 2004.

[2] S.H. Al-Hamdani, and S.L. Blair, "Influence of copper on selected physiological responses in S. minima and its potential use in copper remediation” Am. Fern J., vol. 94, no 1, pp. 47-56, 2004.

[3] M.S. Li, Y.P Luo, and Z.Y. Su, "Heavy metal concentrations in soils and plant accumulation in a restored manganese mineland in Guangxi, South China" Environ. Pollut., vol. 147, pp. 168-175, 2007.

[4] E.J. Olguín, E. Hernández, and I. Ramos, "The effect of both different light conditions and the $\mathrm{pH}$ value on the capacity of Salvinia minima Baker for removing cadmium, lead and chromium" Acta Biotechnol., vol. 22, no 1-2, pp. 121-131, 2002.

[5] M.D. Vázquez, J. Lopez, and A. Carballeira, "Uptake of Heavy Metals to the Extracellular and Intracellular Compartments in Three Species of Aquatic Bryophyte" Ecotox. Environ. Saf., vol. 44, pp. 12-24, 1999.

[6] N. Noraho, and J.P. Gaur, "Cadmium adsorption and intracellular uptake by two macrophytes, Azolla pinnata and Spirodela polyrhiza".Arch. Hydrobiol., vol. 136, pp. 135-144, 1996.

[7] E.J. Olguín, G. Sánchez-Galván, T. Pérez-Pérez, and A. Pérez-Orozco, "Surface adsorption, intracellular accumulation and compartmentalization of $\mathrm{Pb}$ (II) in batch-operated lagoons with Salvinia minima as affected by environmental conditions, EDTA and nutrients". J. Ind. Microbiol. Biotechnol., vol. 32, pp. 577-586, 2005.

[8] APHA, AWWA, WPCF. Standard Methods for the Examination of Water and Wastewater-21th Ed. American Public Health Association, American Water Works Association, and Water Pollution Control Federation, Washington, DC. 2005.

[9] A. Zayed, G. Suvarnalatha, and N. Terry, "Phytoaccumulation of trace elements by wetlands plants: I Duckweed" J. Environ. Qual., vol. 3, pp. 715-721, 1998.

[10] H. Marschener, "Mineral nutrition of higher plants", $2^{\text {nd }}$ edition Ed. Academic Press, San Diego, CA, 1995

[11] E. Epstein, and A.J. Bloom, "Mineral nutrition of plants: principles and perspectives", 2nd ed. Sinauer Associates Inc, Sunderland, MA, 2005.
[12] M. Ater, N. Aït Ali, and H. Kasmi, "Tolérance et accumulation du cuivre et du chrome chez deux espèces de lentilles d'eau : Lemna minor L. et Lemna gibba L. "Revue des Sciences de l'Eau, vol. 19, pp. 57-67, 2006. URI: http://id.erudit.org/iderudit/012597ar DOI: 10.7202/012597ar.

[13] N. Verbruggen, C. Hermans, and H. Schat, "Mechanisms to cope with arsenic or cadmium excess in plants" Curr. Opin. Plant Biol., vol. 12, pp. 364-372, 2009

[14] M. Sela, E. Tel-or, E. Fritz, and A. Huttermann, "Localization and Toxic Effects of Cadmium, Copper, and Uranium in Azolla”.Plant Physiol., vol. 88, pp. 30-36, 1988.

[15] M.A. Maine, N.L. Suñé, and S.C. Lagger, "Chromium bioaccumulation: comparison of the capacity of two floating aquatic macrophytes" Water Res., vol. 38, pp. 1494-1501, 2004.

[16] G.R. MacFarlane, and M.D. Burchett, "Cellular distribution of copper, lead and zinc in the grey mangrove, Avicennia marina (Forsk.)" Vierh. Aquat. Bot., vol. 68, pp. 45-59, 2000.

[17] P.A. Mangabeira, A.S. Ferreira, A.A.F. de Almeida, V.F. Fernandes, E. Lucena, V.L. Souza, A.J. dos Santos Junior, A.H. Oliveira, M.F. Grenier-Loustalot, F. Barbier, and D.C. Silva, "Compartmentalization and ultrastructural alterations induced by chromium in aquatic macrophytes" Biometals, vol. 24, pp. 1017-1026, 2011. DOI 10.1007/s10534-011-9459-9.

[18] H. Roschzttardtz, G. Conéjéro, F. Divol, C. Alcon, J.L. Verdei, C. Curie, and S. Mari, "New insights into Fe localization in plant tissues" Front. Plant Sci., vol. 4, Article 350, 2013. DOI: 10.3389/fpls.2013.00350

[19] I. Yruela, "Copper in plants" Braz. J. Plant Physiol., vol. 17, no. 1, pp. 145-156, 2005.

[20] C. Mouvet, and B. Claveri, "Localization of copper accumulated in Rhynchostegium riparioides using sequential chemical extraction” Aquat. Bot., vol. 63, pp. 1-10, 1999.

[21] H. Mokhtar, N. Morad, and F.F. Ahmad Fizri, "Phytoaccumulation of copper from aqueous solutions using Eichhornia crassipes and Centella asiatica" Int. J. Environ. Sci. Develop., vol. 2, no. 3, pp. 46-52, 2011.

[22] W. Xing, W. Huang, and G. Liu, "Effect of excess iron and copper on physiology of aquatic plant Spirodela polyrrhiza (L.) Schleid” Environ. Toxicol., vol. 25, pp. 103-112, 2010.

[23] J. Kaduková, and E. Virčiková, "Comparison of differences between copper bioaccumulation and biosorption" Environ. Int., vol. 31, pp. 227-232, 2005.

[24] P. Wang, K.A.C. De Schamphelaere, P.M. Kopittke, D.M. Zhou, W.J. Peijnenburg, and K. Lock, "Development of an electrostatic model predicting copper toxicity to plants" J. Exp. Bot., vol. 63, no. 2, pp. 659-668, 2012. DOI:10.1093/jxb/err254. 